\title{
Non-Nutritive Sucking Habits, Anterior Open Bite and Associated Factors in Brazilian Children Aged 30-59 Months
}

\author{
Flávia Maria Nassar de VASCONCELOS \\ Andreza Cristina de Lima Targino MASSONI \\ Mônica Vilela HEIMER \\ Angela Maria Brito FERREIRA \\ Cíntia Regina Tornisiello KATZ \\ Aronita ROSENBLATT
}

Department of Preventive and Community Dentistry, Dental School, University of Pernambuco, Camaragibe, PE, Brazil

\begin{abstract}
The aim of the present study was to investigate the prevalence of non-nutritive sucking habits and anterior open bite as well as their main causes (associated factors) in Brazilian children aged 30-59 months. A cross-sectional study was carried out during the National Immunization Day for polio in the city of Recife in the northeastern region of Brazil. The sample was made up of 1,308 children. Data were collected from interviews with mothers or guardians as well as from clinical examinations carried out by previously trained dental students. The chi-square test was used for statistical analysis at 5\% significance level. The prevalence of non-nutritive sucking habits was $40 \%$, and the habits were associated with gender $(\mathrm{p}=0.001)$, age $(\mathrm{p}=0.003)$ and feeding type $(\mathrm{p}<0.001)$. Anterior open bite was detected in $30.4 \%$ of children, and it was significantly associated with feeding type $(\mathrm{p}<0.001)$ and non-nutritive sucking habits $(\mathrm{p}<0.001)$. The variables found to be associated factors in the present study for the occurrence of non-nutritive sucking habits and anterior open bite emphasize the need to establish strategies that include orientation regarding health promotion based on the "common determining factors" approach. Public health policies should be adopted to encourage a longer duration of breastfeeding, thereby contributing towards reducing the prevalence of non-nutritive sucking habits and anterior open bite.
\end{abstract}

Key Words: epidemiology, habits, prevalence, child.

\section{INTRODUCTION}

Non-nutritive sucking is a common behavior among young children in various populations (1-3). Its prevalence is quite variable and depends on several factors, including gender, age, feeding method and socioeconomic status (1). There is an agreement among a number of authors that non-nutritive sucking habits can be a consequence of industrialization and modernization, with more women working and a shorter breastfeeding period, which favors the adoption of digital and pacifier sucking (1).

Recent studies on determining factors of anterior open bite reveal that non-nutritive sucking habits (pacifier and finger) are the main reasons for this type of malocclusion $(2,3)$. Other factors associated to anterior open bite include breathing pattern (4), skeletal patterns (5), early weaning and dental caries (3). It is important to obtain knowledge of the consequences of non-nutritive sucking habits, anterior open bite, as well as their prevalence and associated factors.

The aim of the present study was to investigate the prevalence of non-nutritive sucking habits and anterior open bite as well as the associated determining factors in Brazilian children aged 30-59 months.

\section{MATERIAL AND METHODS}

A cross-sectional study was conducted in the city of Recife, the state capital of Pernambuco in the northeastern region of Brazil. The study received approval from the Human Research Ethics Committee 
of the Universidade de Pernambuco, Brazil.

The inclusion criteria were children attending health centers on the day of the National Immunization Campaign, accompanied by parents or guardians who agreed to allow the dental examination and signed an informed consent form. Those who had treatment needs were referred to either the healthcare units or the dental school. The sample was made up of male and female children from 30 to 59 months of age.

Recife is divided into 6 administrative districts. Two health centers in each district were randomly selected, each located in a different neighborhood. Pernambuco is the state with the greatest vaccine coverage in Brazil, reaching $100 \%$ of the target population.

The sample size was calculated using the Epi-Info 6.0 software program. The total population of children under the age of 5 years who had been immunized in the previous campaign was 133,797 . The sample was determined base on an estimate of $10 \%$ as the lowest prevalence found among the variables studied, precision index of $2 \%$ and reliability index of $95 \%$. A minimal total sample of 859 children was considered to be representative. However, 1,308 children participated in the study.

Data were recorded on an electronic form following the model adopted by the Forsyth Institute, Boston, MA, USA for optical reading. The questions on the response card had been previously validated in a pilot study. Mothers or guardians were asked about family income, presence of non-nutritive sucking habits (pacifier and/or digit sucking) and feeding type of children.

The clinical examination was performed and charted under natural light, with the child held by the mother in the knee-to-knee position either in the courtyard or in rooms at the health unit. Caps, masks, gloves and gauze were used in compliance with the precepts of infection control. When the posterior teeth were in occlusion, anterior open bite was recorded as the presence of a lack of vertical overlap equal to or greater than $3 \mathrm{~mm}$ between the primary incisors (2).

The reading of the electronic forms was performed by the Opscan 5 machine. The Stantools version 1.4 software program (National Computer Systems) was used for the reading of the marks, edition of errors and the generation of a text file in a Word document. The data from this text file were transferred to a spreadsheet on the Excel software. The SAS (Statistical Analysis
System-Cary, NC) version 8.0 and SPSS (Statistical Package for the Social Sciences-Chicago, Ill) version 13.0 were used for the statistical calculations. The chisquare test was used to assess the association between variables. Multivariate analysis was used to determine interactions among the main variables. Significance was predetermined at $\mathrm{p}<0.05$.

\section{RESULTS}

It was observed that most children (53.0\%) were male and $(56.7 \%)$ belonged to families with a monthly income equal to the national minimum salary (US\$ 140 ) or less. Just over half of the children were bottle fed $(50.7 \%)$ and $60.0 \%$ had not non-nutritive sucking habits. The prevalence of the anterior open bite was $32 \%$ (Table 1).

Table 1 also displays the data on non-nutritive sucking habits according to the independent variables. There was a statistically significant association between non-nutritive sucking habits and gender $(\mathrm{p}=0.001)$, age $(\mathrm{p}=0.003)$ and feeding type $(\mathrm{p}<0.001)$.

Table 2 displays the occurrence of anterior open bite according to the independent variables. The prevalence of anterior open bite was significantly associated with feeding type $(\mathrm{p}<0.001)$ and non-nutritive sucking habits $(\mathrm{p}<0.001)$.

\section{DISCUSSION}

The present study investigated a sample made up of children between the ages 30 and 59 months, with a slight predominance of the male gender. The children belonged to low-income families, the majority of which earned one minimum wage a month. Investigating factors such as gender, age and socioeconomic status is important in the study of non-nutritive sucking habits and malocclusions, as more adequate prevention measures can be established.

The prevalence of sucking habits in the present study $(40 \%)$ was higher than that found in previous studies $(1,2)$. However, the present study corroborates other studies reporting that the prevalence of sucking habits seems to be high among children in industrialized countries $(1,6-8)$. Recife is a large urban center and its economy is concentrated in the secondary and tertiary sectors (industry, commerce and services), which is a pattern similar to that of other large industrial centers in the world. 
The most prevalent feeding type was bottle feeding, which is in agreement with the findings of other authors (6). The world's industrialization and modernization, which requires the participation of females in the labor force, has led to a reduction in breast feeding (1). As stated earlier, Recife is a large urban center and its population has cultural habits similar to those of other developing countries (8). This aspect may explain the higher prevalence of bottle feeding in the city.

The prevalence of anterior open bite in the present study (32\%) was higher than that found by Sousa et al (9), but lower than that described by Peres et al. (3). This variation in prevalence may be explained by differences in sample composition. In the present study, the age range was 30 to 59 months.

In the present study, regarding the factors that could be associated with non-nutritive sucking habits, these factors were significantly determined by gender $(p=0.001)$, age $(p=0.003)$ and feeding type $(p<0.001)$.

Regarding gender, it was observed that non-

Table 1. Results for non-nutritive sucking habits according to gender, age (in months), family income and feeding type.

\begin{tabular}{|c|c|c|c|c|c|c|c|c|}
\hline \multirow{3}{*}{ Variable } & \multicolumn{4}{|c|}{ Non-nutritive sucking habits } & & & \multirow{3}{*}{ p-value } & \multirow{3}{*}{ OR $(95 \% \mathrm{CI})$} \\
\hline & \multicolumn{2}{|c|}{ Present } & \multicolumn{2}{|c|}{ Absent } & \multicolumn{2}{|c|}{ Total } & & \\
\hline & $\mathrm{n}$ & $\%$ & $\mathrm{n}$ & $\%$ & $\mathrm{n}$ & $\%$ & & \\
\hline \multicolumn{9}{|l|}{ Gender } \\
\hline Male & 247 & 35.6 & 446 & 64.4 & 693 & 100.0 & $\mathrm{p}^{(1)}=0.001^{*}$ & 1.00 \\
\hline Female & 276 & 44.9 & 339 & 55.1 & 615 & 100.0 & & 1.47 (1.18 to 1.84$)$ \\
\hline Total group & 523 & 40.0 & 785 & 60.0 & 1308 & 100.0 & & \\
\hline \multicolumn{9}{|l|}{ Age (in months) } \\
\hline 30 to 35 & 108 & 48.0 & 117 & 52.0 & 225 & 100.0 & $\mathrm{p}^{(1)}=0.003^{*}$ & $1.97(1.36$ to 2.85$)$ \\
\hline 36 to 41 & 137 & 44.1 & 174 & 55.9 & 311 & 100.0 & & 1.68 (1.19 to 2.37$)$ \\
\hline 42 to 47 & 94 & 39.2 & 146 & 60.8 & 240 & 100.0 & & $1.37(0.95$ to 1.99$)$ \\
\hline 48 to 53 & 102 & 37.1 & 173 & 62.9 & 275 & 100.0 & & $1.26(0.88$ to 1.80$)$ \\
\hline 54 to 59 & 82 & 31.9 & 175 & 68.1 & 257 & 100.0 & & 1.00 \\
\hline Total group & 523 & 40.0 & 785 & 60.0 & 1308 & 100.0 & & \\
\hline \multicolumn{9}{|l|}{$\begin{array}{l}\text { Family income } \\
\text { (in minimum wage) }^{(2)}\end{array}$} \\
\hline$\leq 1$ minimum wage & 303 & 40.9 & 438 & 59.1 & 741 & 100.0 & $\mathrm{p}^{(1)}=0.738$ & $1.11(0.81$ to 1.53$)$ \\
\hline Between 1 and 4 & 144 & 39.0 & 225 & 61.0 & 369 & 100.0 & & $1.03(0.72$ to 1.47$)$ \\
\hline More than $4 \times$ & 76 & 38.4 & 122 & 61.6 & 198 & 100.0 & & 1.00 \\
\hline Total group & 523 & 40.0 & 785 & 60.0 & 1308 & 100.0 & & \\
\hline \multicolumn{9}{|l|}{ Feeding type } \\
\hline Breastfeeding & 17 & 14.7 & 99 & 85.3 & 116 & 100.0 & $\mathrm{p}^{(1)}<0.001^{*}$ & 1.00 \\
\hline Bottle feeding & 351 & 52.9 & 312 & 47.1 & 663 & 100.0 & & $6.55(3.83$ to 11.21$)$ \\
\hline Both & 50 & 39.7 & 76 & 60.3 & 126 & 100.0 & & 3.83 (2.05 to 7.17$)$ \\
\hline None & 105 & 26.1 & 298 & 73.9 & 403 & 100.0 & & 2.05 (1.17 to 3.59$)$ \\
\hline Total group & 523 & 40.0 & 785 & 60.0 & 1308 & 100.0 & & \\
\hline
\end{tabular}

(*): Significant association to 5\%; (1): Pearson's chi-square test; (2): Monthly minimum wage when the study was conducted (US\$ 140 ); OR: odds ratio; CI: confidence interval. 
nutritive sucking habits were more frequent among girls (44.9\%), which corroborate results reported previously (10). There is no consensus in the scientific literature to explain the prevalence of this habit among women. A more thorough investigation of the psychological differences between the genders will certainly help clarifying this question (10).

The increase in age led to a reduction in nonnutritive sucking habits, which was also observed by other authors $(2,8,11)$. This result is relevant and positive from the orthodontic point of view because the damage caused by oral habits can be corrected spontaneously

Table 2. Results for anterior open bite according to gender, age (in months), family income, feeding type and non-nutritive sucking habit.

\begin{tabular}{|c|c|c|c|c|c|c|c|c|}
\hline \multirow{3}{*}{ Variable } & \multicolumn{4}{|c|}{ Anterior open bite } & & & \multirow{3}{*}{ p-value } & \multirow{3}{*}{ OR $(95 \% \mathrm{CI})$} \\
\hline & \multicolumn{2}{|c|}{ Present } & \multicolumn{2}{|c|}{ Absent } & \multicolumn{2}{|c|}{ Total } & & \\
\hline & $\mathrm{n}$ & $\%$ & $\mathrm{n}$ & $\%$ & $\mathrm{n}$ & $\%$ & & \\
\hline \multicolumn{9}{|l|}{ Gender } \\
\hline Male & 208 & 30.0 & 485 & 70.0 & 693 & 100.0 & $\mathrm{p}^{(1)}=0.097$ & 1.00 \\
\hline Female & 211 & 34.3 & 404 & 65.7 & 615 & 100.0 & & $1.22(0.97$ to 1.54$)$ \\
\hline Total group & 419 & 32.0 & 889 & 68.0 & 1308 & 100.0 & & \\
\hline \multicolumn{9}{|l|}{ Age (in months) } \\
\hline 30 to 35 & 75 & 33.3 & 150 & 66.7 & 225 & 100.0 & $\mathrm{p}^{(1)}=0,193$ & $1.36(0.92$ to 2.01$)$ \\
\hline 36 to 41 & 113 & 36.3 & 198 & 63.7 & 311 & 100.0 & & $1.56(1.09$ to 2.23$)$ \\
\hline 42 to 47 & 76 & 31.7 & 164 & 68.3 & 240 & 100.0 & & $1.26(0.86$ to 1.86$)$ \\
\hline 48 to 53 & 86 & 31.3 & 189 & 68.7 & 275 & 100.0 & & $1.24(0.85$ to 1.81$)$ \\
\hline 54 to 59 & 69 & 26.9 & 188 & 73.2 & 257 & 100.0 & & 1.00 \\
\hline Total group & 419 & 32.0 & 889 & 68.0 & 1308 & 100.0 & & \\
\hline \multicolumn{9}{|l|}{$\begin{array}{l}\text { Family income } \\
\text { (in minimum wage) }^{(2)}\end{array}$} \\
\hline$\leq 1 \times$ minimal wage & 247 & 33.3 & 494 & 66.7 & 741 & 100.0 & $\mathrm{p}^{(1)}=0,212$ & 1.37 (0.96 to 1.94$)$ \\
\hline Between 1 and $4 \times$ & 119 & 32.3 & 250 & 67.7 & 369 & 100.0 & & $1.30(0.89$ to 1.91$)$ \\
\hline More than $4 \times$ & 53 & 26.8 & 145 & 73.2 & 198 & 100.0 & & 1.00 \\
\hline Total group & 419 & 32.0 & 889 & 68.0 & 1308 & 100.0 & & \\
\hline \multicolumn{9}{|l|}{ Feeding type } \\
\hline Breastfeeding & 14 & 12.1 & 102 & 87.9 & 116 & 100.0 & $\mathrm{p}^{(1)}<0.001 *$ & 1.00 \\
\hline Bottle feeding & 285 & 43.0 & 378 & 57.0 & 663 & 100.0 & & $5.49(3.08$ to 9.81$)$ \\
\hline Both & 34 & 27.0 & 92 & 73.0 & 126 & 100.0 & & $2.69(1.36$ to 5.33$)$ \\
\hline None & 86 & 21.3 & 317 & 78.7 & 403 & 100.0 & & 1.98 (1.08 to 3.63$)$ \\
\hline Total group & 419 & 32.0 & 889 & 68.0 & 1308 & 100.0 & & \\
\hline \multicolumn{9}{|l|}{$\begin{array}{l}\text { Non-nutritive sucking } \\
\text { habit }\end{array}$} \\
\hline Present & 356 & 68.1 & 167 & 31.9 & 523 & 100.0 & $\mathrm{p}^{(1)}<0.001^{*}$ & 24.43 (17.80 to 33.52$)$ \\
\hline Absent & 63 & 8.0 & 722 & 92.0 & 785 & 100.0 & & 1.00 \\
\hline Total group & 419 & 32.0 & 889 & 68.0 & 1308 & 100.0 & & \\
\hline
\end{tabular}

(*): Significant association to $5.0 \%$; (1): Pearson's chi-square test; (2): Monthly minimum wage when the study was conducted (US\$ 140); OR: odds ratio; CI: confidence interval. 
after their cessation (12). Góis et al. (13) reported the importance of stopping the pacifier-sucking habit by the age of 2 in order to reduce the risk of malocclusions, and highlights that it is important to observe not only the presence of the pacifier-sucking habit, but also when it has ceased.

Feeding type can also be considered an etiological factor in the establishment of non-nutritive sucking habits and children who were breastfeed are less likely to develop such habits $(6,7)$. Likewise, a significant association was found between feeding type and the presence of non-nutritive sucking habits, as children who were bottle fed had a higher prevalence of nonnutritive sucking habits.

Our findings show the need to investigate other factors that can be associated with the prevalence of nonnutritive sucking habits, such as psychological aspects. For example, the mother-child relationship needs to be examined more thoroughly. The subjectivity of this relationship is of extreme importance in the etiology of non-nutritive sucking habits (10).

The etiology of malocclusions, such as anterior open bite, is multifactorial, with an interaction of congenital, morphological, biomechanical and environmental factors (14). In the present study, the prevalence of anterior open bite was significantly associated with feeding type and non-nutritive sucking habits, but was not associated with age, gender or family income, which is in agreement with findings described elsewhere (3). Previous studies $(1,2,4)$ have described a significant reduction in the prevalence of anterior open bite with age, which is corroborated by the findings in the present study. The cause of this decline may be changes in growth, dental alterations and a decrease in the prevalence of harmful habits.

Another variable commonly evaluated in relation to anterior open bite is the, for which there was a significant association in this study. Breastfeeding was found to be a protective factor, which disagrees with the results of Larsson (15), but agree with those of Leite-Cavalcanti et al. (7). The positive effects of breastfeeding on the normal development of occlusion may be explained by the effect of sucking on the skeletal and muscular development of the child's face. Sucking mechanics differs between children who are breastfed and those who are bottle fed. Breastfeeding promotes the correct development of the jaws, strengthening the muscles involved in the process of sucking to obtain breast milk (7).

The high frequency of anterior open bite in children with non-nutritive sucking habits is supported by previous findings in the literature $(2,3)$. However, it should be stressed that self-correction of anterior open bite may occur after the cessation of sucking habits during the primary dentition $(2,13,15,16)$. This confirms the importance of intensity-duration-frequency of habits in the development and maintenance of malocclusion (7).

In conclusion, the findings of the present study reveal that the prevalence of non-nutritive sucking habits was high in this population. Gender, age and feeding type were associated factors for the occurrence of non-nutritive sucking habits. Anterior open bite was associated with feeding type and non-nutritive sucking habits. The variables found to be associated factors in the present study for the occurrence of non-nutritive sucking habits and anterior open bite emphasize the need to establish strategies that include orientation regarding health promotion based on the "common determining factors" approach. Thus, public health policies should be adopted to encourage a longer duration of breastfeeding, thereby contributing towards reducing the prevalence of non-nutritive sucking habits and anterior open bite.

\section{RESUMO}

O objetivo do presente estudo foi avaliar a prevalência de hábitos de sucção não nutritiva e mordida aberta anterior, assim como, determinar os seus fatores de risco (fatores associados) em crianças brasileiras de 30-59 meses. Um estudo transversal foi realizado durante o Dia Nacional de Vacinação contra a pólio na cidade do Recife, situada na região nordeste do Brasil. A amostra foi composta por 1308 crianças. Os dados foram coletados a partir de entrevistas com as mães ou responsáveis, bem como, de exames clínicos realizados por estudantes de odontologia, previamente treinados. O teste qui-quadrado foi utilizado para análise estatística com nível de significância de 5\%. A prevalência de hábitos de sucção não nutritiva foi de $40 \%$, e os hábitos estavam associados com sexo $(p=0,001)$, idade $(p=0,003)$ e tipo de alimentação $(p<0,001)$. A mordida aberta anterior foi detectada em $30,4 \%$ das crianças. A mordida aberta anterior foi significativamente associada com o tipo de alimentação $(\mathrm{p}<0,001)$ e hábitos de sucção não nutritiva $(\mathrm{p}<0,001)$. No presente estudo, as variáveis consideradas fatores associados para a ocorrência de hábitos de sucção não nutritiva e mordida aberta anterior enfatizam a necessidade de estabelecer estratégias que incluam a orientação sobre a promoção da saúde baseada na abordagem dos "fatores de risco comum". Deste modo, as políticas públicas de saúde devem ser adotadas para incentivar uma maior duração do aleitamento materno, contribuindo, assim, para reduzir a prevalência de hábitos de sucção não nutritiva e mordida aberta anterior.

\section{REFERENCES}

1. Farsi NM, Salama FS. Sucking habits in Saudi children: 
prevalence, contributing factors and effects on the primary dentition. Pediatr Dent 1997;19:28-33.

2. Katz CRT, Rosenblatt A. Non-nutritive sucking habits and anterior open bite in Brazilian children: A Longitudinal Study. Pediatr Dent 2005;27:1-5.

3. Peres KG, Barros AJ, Peres MA, Victora CG. Effects of breastfeeding and sucking habits on malocclusion in a birth cohort study. Rev Saude Pública 2007;41:343-350.

4. Klocke A, Nanda RS, Kahl-Nieke B. Anterior open bite in the deciduous dentition: longitudinal follow-up and craniofacial growth considerations. Am J Orthod Dentofacial Orthop 2002;122:353-358.

5. Yousefzadeh F, Shcherbatyy V, King GJ, Huang GJ, Liu ZJ. Cephalometric and electromyographic study of patients of East African ethnicity with and without anterior open bite. Am J Orthod Dentofacial Orthop 2010;137:236-246.

6. Degan VV, Puppin-Rontani RM. Prevalence of pacifier- sucking habits and successful methods to eliminate them - a preliminary study. J Dent Child 2005;71:148-151.

7. Leite-Cavalcanti A, Medeiros-Bezerra PK, Moura C. Breastfeeding, bottle-feeding, sucking habits and malocclusion in Brazilian preschool children. Rev Salud Publica 2007;9:194-204.

8. Macena MCB, Katz CRT, Rosenblatt A. Non-nutritive sucking habits, dental malocclusions, and facial morphology in Brazilian children: a longitudinal study. Eur J Orthod 2008;30:580-585.

9. Sousa RLS, Lima RB, Florêncio Filho C, Lima KC, Diógenes $A M N$. Prevalence and risk factors of anterior open bite in the complete deciduous dentition in pre-scholars' children who live in the city of Natal/RN. Rev Dent Press Ortodon Ortop Facial 2007;12:129-138.

10. Holanda ALF, Santos AS, Sena MF, Ferreira MAF. Relationship between breast- and bottle-feeding and non-nutritive sucking habits. Oral Health Prev Dent 2009;7:331-337.

11. Bishara SE, Warren JJ, Broffitt B, Levyd SM. Changes in the prevalence of non-nutritive sucking patterns in the first 8 years of life. Amer J Orthod Dentofac Orthoped 2006;130:31-36.

12. Mistry P, Moles DR, O'Neill J, Noar J. The occlusal effects of digit sucking habits amongst school children in Northamptonshire (UK). J Orthod 2010;37:87-92.

13. Góis EGO, Ribeiro Júnior HC, Vale MPP, Paiva SM, Serra-Negra JMC, Ramos-Jorge ML, et al.. Influence of nonnutritive sucking habits, breathing pattern and adenoid size on the development of malocclusion. Angle Orthod 2008;78:647-654.

14. Vig KWL, Fields HW. Facial growth and management of orthodontic problems. Pediatr Clin North Amer 2000;47:10851123.

15. Larsson E. Sucking, chewing, and feeding of young children. Swed Dent J 2001;71:116-119.

16. Yemitan TA, da Costa OO, Sanu OO, Isiekwe MC. Effects of digit sucking on dental arch dimensions in the primary dentition. Afr J Med Med Sci 2010;39:55-61. 